УДК 342.9(477)

\title{
ПОДАТКОВІ НАСЛІДКИ ТА РИЗИКИ ЗАСТОСУВАННЯ МИТНИХ РЕЖИМІВ
}

\section{TAX CONSEQUENCES AND RISKS OF APPLICATION OF CUSTOMS REGIMES}

\author{
Найденко Олексій Євгенович \\ кандидат економічних наук, доцент, \\ Харківський національний економічний університет \\ імені Семена Кузнеця \\ ORCID: https://orcid.org/0000-0003-0638-3965 \\ Островський Денис Миколайович \\ викладач, \\ Харківський національний економічний університет \\ імені Семена Кузнеця \\ ORCID: https://orcid.org/0000-0001-7615-7774 \\ Азізова Катерина Михайлівна \\ кандидат економічних наук, доцент, \\ Харківський національний економічний університет \\ імені Семена Кузнеця \\ ORCID: https://orcid.org/0000-0003-0539-5489
}

\author{
Naidenko Oleksii, Ostrovskyi Denys, Azizova Kateryna \\ Simon Kuznets Kharkiv National University of Economics
}

\begin{abstract}
У статті розглянуто особливості застосування митних режимів згідно. Проаналізовано підходи до класифікації митних режимів та доведено необхідність класифрікації митних режимів на завершені та незавершені. Визначено, що у кожному митному режимі на законодавчому рівні закладено обмежувальні та стимулюючі заходи. Доведено, що при застосуванні митних режимів мають враховуватися інтереси суб'єктів зовнішньоекономічної діяльності та держави. Охарактеризовано підходи до класифрікації митних режимів в країнах ЄС. Проаналізовано історичні аспекти виникнення та застосування митних режимів. Деталізовано умови, обмеження та вимоги, які ставляться до митних режимів в Україні. Обґрунтовано реалізацію функцій митних режимів. Проаналізовано митні пільги, які можуть застосовуватися згідно податкового та митного законодавства. Виокремлено ризики застосування митних режимів. Охарактеризовано податкові наслідки застосування митних режимів при справлянні податку на додану вартість, акцизного податку та мита. Обґрунтовано рекомендації щодо адаптації українського митного законодавства до митного законодавства ЄС щодо класифікації митних режимів.
\end{abstract}

Ключові слова: мито, митна політика, митні режими, митні пільги, митні процедури, митні формальності, митні ризики.

В статье рассмотрены особенности применения таможенных режимов. Проанализированы подходы к классификации таможенных режимов. Определено, что в каждом таможенном режиме на законодательном уровне заложено ограничительные и стимулирующие меры. Доказано, что при применении таможенных режимов должны учитываться интересы субъектов внешнеэкономической деятельности и государства. Охарактеризованы подходы к классификации таможенных режимов в странах ЕС. Проанализированы исторические аспекты возникновения и применения таможенных режимов. Детализировано условия, ограничения и требования, предъявляемые к таможенным режимам в Украине. Обосновано реализацию функций таможенных режимов. Проанализированы таможенные льготы, которые могут применяться согласно налогового и таможенного законодательства. Выделены риски применения таможенных режимов. Охарактеризованы налоговые последствия применения таможенных режимов при взимании налога на добавленную стоимость, акцизного налога и пошлины. Обоснованы рекомендации по адаптации украинского таможенного законодательства таможенного законодательства ЕC по классификации таможенных режимов.

Ключевые слова: таможенная пошлина, таможенная политика, таможенные режимы, таможенные льготы, таможенные процедуры, таможенные формальности, таможенные риски. 
The article discusses the features of the application of customs regimes in accordance with the Customs Code of Ukraine. Approaches to the classification of customs regimes have been analyzed and the necessity of classification of customs regimes completed and incomplete has been proved. It was determined that restrictive and stimulating measures are laid down in each customs regime at the legislative level. It has been proved that when applying customs regimes, the interests of subjects of foreign economic activity and the state must be taken into account. The goal of the state when applying customs regimes is to protect national producers, stimulate priority activities for the state and introduce certain prohibitions in order to ensure their economic interests, and increase customs revenues. The interests of the subject of foreign economic activity are to simplify customs formalities, optimize customs taxation in the direction of decreasing, and reduce non-tariff barriers. The approaches to the classification of customs regimes in the EU countries are characterized and it is established that in the EU customs regimes are divided into release for free circulation; export; special procedures. The historical aspects of the emergence and application of customs regimes are analyzed. The conditions, restrictions and requirements for customs regimes in Ukraine are detailed. The implementation of the functions of customs regimes is substantiated: fiscal, protective and stimulating. It was determined that the main characteristics of customs regimes in Ukraine: direction of movement of goods (import, export, transit) conditions for placing goods in a certain customs regime; country of origin; the purpose of the move; rules for the use, possession and disposal of this product; the period of validity of the regime, the customs status of goods, the procedure for paying tax and customs payments; the procedure for completing the customs regime; responsibility of persons for violation of the customs regime. Analyzed the customs benefits that can be applied in accordance with tax and customs legislation. The risks of using customs regimes are highlighted. The tax consequences of the application of customs regimes in the collection of value added tax, excise tax and duties are characterized. Recommendations for the adaptation of the Ukrainian customs legislation to the EU customs legislation on the classification of customs regimes are substantiated.

Keywords: customs duty, customs policy, customs regimes, customs privileges, customs procedures, customs formalities, customs risks.

Постановка проблеми. Митні режими є одним із важливих інструментів державної митної політики, за допомогою якого визначається порядок переміщенні товарів і транспортних засобів через митну територію України. Завдяки митній політиці держави забезпечується ії національна безпека. Застосування митних режимів здійснюється з метою забезпечення економічної безпеки держави. За допомогою тарифнних та нетарифних заходів регулювання ЗЕД, які набувають практичного втілення в митних режимах, здійснюється захист національних товаровиробників.

Завдяки імплементації митного законодавства ЄС в Україні змінюється підхід до проведення митного оформлення товарів, процедури митного контролю, застосування методів регулювання залежно від митного режиму, в якому товари будуть ввозитися на митну територію України чи вивозитися за її межи. Різні види митних режимів передбачають відмінні правила оподаткування ЗЕД. Залежно від обраного митного режиму регулюється порядок подальшого використання, реалізації відповідних товарів та транспортних засобів, права та обов'язки їх власника, митний статус товарів, порядок повернення сум мита тощо.

Окрім того, застосування певного виду митного режиму може передбачати ризики їх реалізації.

Аналіз останніх досліджень і публікацій. Проблеми застосування митних режимів розглядалися багатьма науковцями.
Так, Р. Лемеха $[1$, с. 123] стверджує, що важливим напрямом удосконалення правового регулювання митних відносин $€$ адаптація українського законодавства до вимог $€ C$, в тому числі і митних режимів.

Н. Осадча та В. Ляшенко [2, с. 352] вважають, що митні режими можуть бути систематизовані на три групи: режими, які впливають на сальдо торгівельного балансу, глобалізаційні та національні митні режими.

На думку Б. Кормича [3, с. 151], важливим $€$ реалізація завдань щодо наближення митного законодавства України до вимог митного законодавства $€ С$, вимагає як внесення змін до Митного кодексу 3 метою встановлення гармонізованого терміну «митна процедура» замість теперішнього митного режиму.

Тучак Т. В. [4, с. 53] зосереджує увагу на тому, що правове регулювання митних режимів, розроблене в ЄС, є більш сприятливим для розвитку експортноорієнтованих галузей виробництва, створення додаткових робочих місць та збільшення податкових відрахувань підприємствами.

Виділення невирішених раніше частин загальної проблеми. Але у проведених дослідженнях не в повній мірі було розглянуто питання податкових наслідків, які виникають при застосуванні певних митних режимів.

Також мають бути деталізовано ризики застосування митних режимів для держава та суб'єктів зовнішньоекономічної діяльності.

Постановка завдання. Метою дослідження $€$ аналіз історичних та теоретичних 
аспектів становлення та розвитку митних режимів, визначення податкових наслідків застосування податкових режимів та обґрунтування ризиків застосування митних режимів для держави та суб'єктів зовнішньоекономічної діяльності.

Виклад основного матеріалу дослідження. Згідно пункту 25 статті 4 Митного кодексу України, митний режим - це комплекс взаємопов'язаних правових норм, що відповідно до заявленої мети переміщення товарів через митний кордон України визначають митну процедуру щодо цих товарів, їх правовий статус, умови оподаткування і обумовлюють їх використання після митного оформлення [5].

В Україні можуть застосовуватися наступні митні режими [5]: імпорт (випуск для вільного обігу); реімпорт; експорт (остаточне вивезення); реекспорт; транзит; тимчасове ввезення; тимчасове вивезення; митний склад; вільна митна зона; безмитна торгівля; переробка на митній території; переробка за межами митної території; знищення або руйнування; відмова на користь держави.

У кожному митному режимі на законодавчому рівні закладено обмежувальні та стимулюючі заходи. Зазвичай обмеження можуть бути у вигляді тарифнних і нетарифних бар'єрів, додаткової системи контролю, дозвільних документів, термінів перебування товарів під митним режимом, скорочення чи продовження термінів використання митного режиму тощо.

Митний режим, як і митна політика загалом, базується на взаємодії національних правил, які визначаються внутрішнім законодавством та міжнародними зобов'язаннями, встановленими міжнародно-правовими актами. Через таку взаємодію забезпечується баланс між національними митними інтересами і відповідними узгодженими міжнародними вимогами [6].

Крім того, при формуванні та використанні митного режиму Н. Осадча [2] та В. Ляшенко [7] рекомендують виокремлювати два типи інтересів (цілей): інтерес підприємця та інтерес держави, які мають бути збалансовані. Дії держави мають бути спрямовані на захист національних товаровиробників, стимулювання пріоритетних для держави видів діяльності та запровадження певних заборон з метою забезпечення своїх економічних інтересів, збільшення митних надходжень. Суб'єкти ЗЕД бажають отримати спрощені митні формальності, оптимізацію митних платежів та зниження нетарифних бар'єрів.

Існують різні наукові підходи до класифікації митних режимів (табл. 1).

Автор підтримує точку зору А. А. Дубініної та інших [11], які в основу класифрікації митних режимів поклали ознаку завершеності дій:

Підходи до класифрікації митних режимів

Таблиця 1

\begin{tabular}{|c|c|}
\hline Автор & Підхід до класифрікації \\
\hline $\begin{array}{c}\text { В. Науменко } \\
\text { [8] }\end{array}$ & $\begin{array}{l}\text { I група - митні режими які застосовуються до основної маси об'єктів } \\
\text { зовнішньоекономічних операцій. } \\
\text { II група - митні режими, які використовуються в межах надання цілої } \\
\text { низки послуг у сфері зовнішньоекономічної діяльності та дозволяють } \\
\text { використовувати товари лише для певних цілей при дотриманні обмежень, } \\
\text { встановлених законодавством; } \\
\text { III група - митні режими, які застосовуються при припиненні ЗЕД-операцій } \\
\text { у зв'язку з неможливістю або неефективністю проведення подальших дій } \\
\text { з товарами на внутрішньому ринку. }\end{array}$ \\
\hline $\begin{array}{c}\text { О. Гребельн } \\
{[9]}\end{array}$ & $\begin{array}{l}\text { 1) режими, які використовуються при здійсненні основного обсягу } \\
\text { зовнішньоторговельних операцій; } \\
\text { 2) митні режими, за яких переміщення товарів через кордон, поєднується } \\
\text { зі здійсненням митними органами конкретних операцій в інтересах } \\
\text { відповідних організацій або осіб з наданням для них певних послуг; } \\
\text { 3) митні режими, в межах яких товари переміщуються через кордон у зв'язку } \\
\text { з їх переробкою в іншій країні; } \\
\text { 4) режими, які використовуються при припиненні зовнішньоекономічних } \\
\text { операцій (у зв'язку з неможливістю або неефрективністю реалізації інших } \\
\text { митних режимів на території України); } \\
\text { 5) режими, зміст яких зводиться до того, що ввезення іноземних товарів } \\
\text { відбувається без сплати митних податків, а також без застосування до даних } \\
\text { товарів заходів нетарифрного регулювання (квотування, ліцензування). }\end{array}$ \\
\hline $\begin{array}{c}\text { М. В. Мельник } \\
{[10]}\end{array}$ & $\begin{array}{l}\text { 1) прості; } \\
\text { 2) триваючі }\end{array}$ \\
\hline
\end{tabular}


завершені митні режими - імпорт, реімпорт, експорт, реекспорт, вільна митна зона, знищення або руйнування, відмова на користь держави;

незавершені митні режими - тимчасове ввезення, тимчасове вивезення, митний склад, безмитна торгівля, переробка на митній території, переробка за межами митної території, транзит.

Норми законодавства України та ЄС щодо митних режимів мають відмінності.

Статтею 5 Митного кодексу ЄC [12] встановлено три основних види митних режимів, до яких належать: випуск для вільного обігу (release for free circulation); експорт (export); спеціальні процедури (special procedures).

Така класифрікація найбільш точно відображає фрункціональне призначення цих процедур - оподаткування та застосування нетарифних заходів економічної політики. Відповідно до цього і виділено дві процедури, в яких тарифне та нетарифоне регулювання застосовується у повній мірі - імпорт та експорт, а також «спеціальні процедури», які передбачають звільнення від такого регулювання за певних умов

Загалом світовий досвід застосування митних режимів має давнішню історію [3].

Наприклад, режим митний склад (customs warehousing) в Англії було запроваджено у 1803 р. для таких товарів, як: чай, тютюн, кава, вино та міцні алкогольні напої. У Франції даний вид режиму було встановлено митним законодавством у 1832 р.

Так само, у даний період починає фрормуватися сучасне поняття транзиту, який спочатку передбачав застосування транзитних мит, які складали певну частку від звичайних імпортних. Скасування транзитних мит в окремих країнах Європи розпочалася лише в середині XIX ст., в той же час інші країни, як наприклад Російська імперія, взагалі не визнавали транзиту як такого, застосовуючи до нього звичайні імпортні мита. Остаточне закріплення свободи транзиту відбулося лише після підписання Барселонської Конвенції про свободу транзиту 1921 р., ст. 3 якої забороняла оподаткування транзитних перевезень як транзитними, так і ввізними та вивізними митами. Правила щодо тимчасового ввезення, причому лише для промислових зразків, були вперше запроваджені у Міжнародній конвенції щодо спрощення митних формальностей, яка була підписана у Женеві 2 листопада 1923 р. [3].

Крім збалансування інтересів держави і суб'єктів ЗЕД, митні режими виконують низку фрункцій [13]: фріскальну, захисна та стимулю- юча. При цьому один і той самий режим може поєднувати в собі елементи кількох видів.

Фіскальна фрункція митних режимів реалізується шляхом справляння митних платежів 3 експортних, імпортних та транзитних операцій.

Захисна фрункція митних режимів передбачає обмеження доступу іноземних товарів на внутрішній ринок, захист інтересів вітчизняних виробників, недопущення на національний ринок неякісної продукції.

Стимулююча фрункція митних режимів спрямована на активізацію зовнішньоторговельного обороту, залучення іноземних інвестицій, створення умов для розвитку окремих галузей промисловості тощо.

Стимулююча фрункція може реалізовуватися також через надання митних пільг, а також незастосування заходів нетарисрного регулювання.

Податкове [14] та митне законодавство [5] передбачає застосування таких видів податкових та митних пільг:

1. тарифрні пільги (тарифрні префреренцій) щодо ставок Митного тарифру України [15].

2. зниження ставок інших митних платежів. Для більшості товарів 3 країн ЄС в Україні встановлено нульову ставку мита;

3. звільнення від оподаткування іншими митними платежами (ПДВ із ввезених на митну територію товарів (продукції), акцизний податок із ввезених на митну територію товарів (продукції));

4. умовне (повне або часткове) звільнення від оподаткування митними платежами.

5. звільнення від оподаткування товарів, які переміщуються через митний кордон України.

Порядок виконання митних фрормальностей відповідно заявленого митного режиму регламентується Митним кодексом України [5] та наказом Міністерства фрінансів України «Про виконання митних фрормальностей відповідно до заявленого митного режиму» від 31.05.2012 р. № 657 [16].

При виконанні митних формальностей за певними митними режимами можуть виникати різноманітні ризики (табл. 2).

Основними платежами, які сплачуються при здійсненні ЗЕД є мито, податок на додану вартість та акцизний податок.

За даними Міністерства фрінансів України [17] в 2019 році питома вага надходжень від податку на додану вартість складала 29,4 \%, акцизного податку з імпорту -4,6\%, вивізного мита-0,02\%, ввізного мита - 2,3 \%. За підсумками 2020 року скоріше за все буде спостерігатися зниження митних платежів, з урахуванням обмежень, які вводилися Україною з-за пандемії. 
Ризики застосування митних режимів

\begin{tabular}{|c|c|c|}
\hline Митний режим & $\begin{array}{c}\text { Ризики застосування митного режиму } \\
\text { для держави }\end{array}$ & $\begin{array}{c}\text { Ризики застосування митного } \\
\text { режиму для платників митних } \\
\text { платежів } \\
\end{array}$ \\
\hline 1 & 2 & 3 \\
\hline Імпорт & $\begin{array}{c}\text { Можливість потрапляння контрабандних } \\
\text { та неякісних товарів на митну територію } \\
\text { України. }\end{array}$ & $\begin{array}{c}\text { Сплата митних платежів залежить від } \\
\text { методу визначення митної вартості, } \\
\text { що може збільшувати кінцеву суму } \\
\text { митних платежів. } \\
\end{array}$ \\
\hline Реімпорт & $\begin{array}{c}\text { Контроль за станом товарами, які } \\
\text { повертаються до України після їх } \\
\text { вивезення в режимі експорту. }\end{array}$ & $\begin{array}{c}\text { Втрата можливості отримати } \\
\text { бюджетне відшкодування ПДВ за } \\
\text { товарами, які були поміщені в митний } \\
\text { режим експорту та повертаються в } \\
\text { Україну в митному режимі реімпорту. }\end{array}$ \\
\hline Експорт & $\begin{array}{c}\text { Необхідність сплати бюджетного } \\
\text { відшкодування ПДВ. }\end{array}$ & $\begin{array}{c}\text { Сплата вивізного мита у випадку } \\
\text { вивезення брухту та відходів чорних } \\
\text { металів, живої худоби та шкіряної } \\
\text { сировини, деякі види олійних культур, } \\
\text { природного газу. }\end{array}$ \\
\hline Реекспорт & $\begin{array}{c}\text { Контроль за станом товарами, які будуть } \\
\text { вивозитися за межі митної території } \\
\text { України після їх вивезення } \\
\text { в режимі імпорту. } \\
\end{array}$ & $\begin{array}{c}\text { Необхідність виконання всіх митних } \\
\text { фрормальностей. }\end{array}$ \\
\hline Транзит & $\begin{array}{c}\text { Контроль за дотриманням строків } \\
\text { транзитних перевезень. }\end{array}$ & $\begin{array}{c}\text { Необхідність дотримання строків } \\
\text { транзитних перевезень. }\end{array}$ \\
\hline Тимчасове ввезення & $\begin{array}{c}\text { Контроль за дотриманням строків } \\
\text { тимчасового ввезення товарів } \\
\text { на митну територію України. }\end{array}$ & $\begin{array}{c}\text { Необхідність дотримання строків } \\
\text { тимчасового ввезення. } \\
\text { Сплата частки митних платежів } \\
\text { за умови умовного часткового } \\
\text { звільнення від оподаткування. } \\
\text { Необхідність застосування } \\
\text { фрінансових гарантій. } \\
\end{array}$ \\
\hline $\begin{array}{l}\text { Тимчасове } \\
\text { вивезення }\end{array}$ & $\begin{array}{c}\text { Контроль за дотриманням строків } \\
\text { тимчасового вивезення товарів за межі } \\
\text { митної території України. } \\
\end{array}$ & $\begin{array}{l}\text { Необхідність дотримання строків } \\
\text { тимчасового вивезення. }\end{array}$ \\
\hline Митний склад & $\begin{array}{c}\text { Контроль за дотриманням строків } \\
\text { зберігання товарів у режимі митного складу. } \\
\text { Контроль за передачею права власності } \\
\text { на іноземні товари. } \\
\end{array}$ & $\begin{array}{c}\text { Необхідність дотримання строків } \\
\text { зберігання товарів у режимі митного } \\
\text { складу. }\end{array}$ \\
\hline Вільна митна зона & $\begin{array}{c}\text { Контроль за переміщенням товарів між } \\
\text { різними вільними митними зонами. } \\
\end{array}$ & $\begin{array}{c}\text { Необхідність сплати вивізного мита за } \\
\text { товарами, на які воно встановлено. } \\
\end{array}$ \\
\hline Безмитна торгівля & $\begin{array}{c}\text { Контроль за переміщенням товарів між } \\
\text { магазинами безмитної торгівлі. }\end{array}$ & $\begin{array}{l}\text { Недоотримання виручки з-за продажу } \\
\text { товарів без ПДВ та акцизного податку. } \\
\end{array}$ \\
\hline $\begin{array}{l}\text { Переробка на митній } \\
\text { території України }\end{array}$ & $\begin{array}{c}\text { Контроль дотриманням строків переробки } \\
\text { товарів на митній території України. } \\
\text { Контроль за використанням дозволів на } \\
\text { переробку товарів на митній території } \\
\text { України. } \\
\text { Контроль за реалізацією продуктів } \\
\text { переробки на митній території України. } \\
\end{array}$ & $\begin{array}{c}\text { Необхідність отримання дозволу } \\
\text { на переробку товарів на митній } \\
\text { території України. } \\
\text { Застосування заходів гарантування. }\end{array}$ \\
\hline $\begin{array}{c}\text { Переробка } \\
\text { за межами митної } \\
\text { території України }\end{array}$ & $\begin{array}{c}\text { Контроль дотриманням строків } \\
\text { переробки товарів за межами митної } \\
\text { території України. } \\
\text { Контроль за використанням дозволів } \\
\text { на переробку товарів за межами митної } \\
\text { території України. } \\
\text { Контроль за реалізацією продуктів } \\
\text { переробки за межами митної території } \\
\text { України. } \\
\end{array}$ & $\begin{array}{c}\text { Необхідність отримання дозволу на } \\
\text { вивезення товарів для переробки } \\
\text { за межами митної території України. } \\
\text { Застосування заходів гарантування. }\end{array}$ \\
\hline $\begin{array}{c}\text { Знищення } \\
\text { або руйнування }\end{array}$ & $\begin{array}{c}\text { Контроль за видами товарів, які будуть } \\
\text { поміщені в даний митний режим. }\end{array}$ & $\begin{array}{c}\text { Отримання письмового дозволу } \\
\text { митного органу для застосування } \\
\text { даного митного режиму. } \\
\end{array}$ \\
\hline $\begin{array}{l}\text { Відмова на користь } \\
\text { держави }\end{array}$ & $\begin{array}{l}\text { Контроль за видами іноземних товарів, } \\
\text { які будуть поміщені в митний режим. }\end{array}$ & $\begin{array}{c}\text { Втрата суми виручки від реалізації } \\
\text { товарів. }\end{array}$ \\
\hline
\end{tabular}


Податкові наслідки застосування митних режимів

Таблиця 3

\begin{tabular}{|c|c|c|c|}
\hline Митний режим & Мито & пдв & Акцизний податок \\
\hline 1 & 2 & 3 & 4 \\
\hline Імпорт & $\begin{array}{c}\text { ввізне мито } \\
\text { нараховується та } \\
\text { сплачується (ст. 280 } \\
\text { Митного кодексу України) }\end{array}$ & \begin{tabular}{|c|} 
нараховується та \\
сплачується відповідно \\
до розділу V Податкового \\
кодексу України (ст. 193)
\end{tabular} & $\begin{array}{c}\text { Нараховується та } \\
\text { сплачується відповідно } \\
\text { до розділу VI Податкового } \\
\text { кодексу України (ст. 215) }\end{array}$ \\
\hline Реімпорт & $\begin{array}{c}\text { ввізне мито } \\
\text { не сплачується } \\
\text { при дотриманні вимог } \\
\text { та обмежень }\end{array}$ & $\begin{array}{c}\text { не сплачується, крім } \\
\text { операцій із ввезення } \\
\text { відповідно до п. } 3 \text { частини } \\
\text { другої ст. } 78 \text { МКУ, що } \\
\text { оподатковуються ПдВ }\end{array}$ & $\begin{array}{c}\text { не сплачується, } \\
\text { якщо при цьому } \\
\text { не справляється ПДВ. } \\
\text { В інших випадках реімпорт } \\
\text { підакцизних товарів 3-за } \\
\text { меж митної території } \\
\text { України оподатковується } \\
\text { акцизним податком }\end{array}$ \\
\hline Експорт & $\begin{array}{c}\text { Не сплачується } \\
\text { за виключенням брухту } \\
\text { та відходів чорних } \\
\text { металів, живої худоби } \\
\text { та шкіряної сировини, } \\
\text { деякі види олійних } \\
\text { культур, природного газу }\end{array}$ & Не сплачується & Не сплачується \\
\hline Реекспорт & Не сплачується & Не сплачується & Не сплачується \\
\hline Транзит & $\begin{array}{c}\text { Не підлягає } \\
\text { оподаткуванню }\end{array}$ & $\begin{array}{c}\text { Не підлягає } \\
\text { оподаткуванню }\end{array}$ & $\begin{array}{c}\text { Не підлягає } \\
\text { оподаткуванню }\end{array}$ \\
\hline $\begin{array}{l}\text { Тимчасове } \\
\text { ввезення }\end{array}$ & $\begin{array}{c}\text { умовне повне та умовне } \\
\text { часткове звільнення } \\
\text { від оподаткування }\end{array}$ & $\begin{array}{c}\text { умовне повне та умовне } \\
\text { часткове звільнення від } \\
\text { оподаткування } \\
\text { або оподаткування } \\
\text { на загальних підставах } \\
\end{array}$ & $\begin{array}{c}\text { умовне повне звільнення } \\
\text { від оподаткування } \\
\text { або сплата на загальних } \\
\text { підставах }\end{array}$ \\
\hline $\begin{array}{l}\text { Тимчасове } \\
\text { вивезення } \\
\end{array}$ & Не сплачується & Не сплачується & Не сплачується \\
\hline Митний склад & $\begin{array}{c}\text { умовне повне звільнення } \\
\text { від оподаткування }\end{array}$ & Не сплачується & Не сплачується \\
\hline $\begin{array}{l}\text { Вільна митна } \\
\text { зона }\end{array}$ & $\begin{array}{c}\text { Нараховується тільки } \\
\text { вивізне мито за товарами, } \\
\text { які оподатковуються } \\
\text { при експорті } \\
\end{array}$ & Не сплачується & Не сплачується \\
\hline $\begin{array}{l}\text { Безмитна } \\
\text { торгівля }\end{array}$ & $\begin{array}{c}\text { Нараховується тільки } \\
\text { вивізне мито за товарами, } \\
\text { які оподатковуються } \\
\text { при експорті }\end{array}$ & Не сплачується & Не сплачується \\
\hline $\begin{array}{l}\text { Переробка } \\
\text { на митній } \\
\text { території } \\
\text { України } \\
\end{array}$ & Не сплачується & Не сплачується & Не сплачується \\
\hline \begin{tabular}{|c|} 
Переробка за \\
межами митної \\
території \\
України
\end{tabular} & $\begin{array}{c}\text { умовне повне та умовне } \\
\text { часткове звільнення } \\
\text { від оподаткування }\end{array}$ & $\begin{array}{c}\text { звільняються від } \\
\text { оподаткування та } \\
\text { застосовується умовне } \\
\text { часткове звільнення від } \\
\text { оподаткування } \\
\end{array}$ & $\begin{array}{c}\text { Нараховується та } \\
\text { сплачується відповідно } \\
\text { до розділу VI Податкового } \\
\text { кодексу України (ставка } \\
\text { податку у ст. 215) }\end{array}$ \\
\hline $\begin{array}{c}\text { Знищення або } \\
\text { руйнування }\end{array}$ & Не сплачується & Не сплачується & Не сплачується \\
\hline $\begin{array}{l}\text { Відмова } \\
\text { на користь } \\
\text { держави }\end{array}$ & Не сплачується & Не сплачується & Не сплачується \\
\hline
\end{tabular}


Розглянемо основні податкові наслідки, які можуть вникнути при застосуванні митних режимів (табл. 3).

Як бачимо, за більшістю митних режимів податкові наслідки виникають, а в деяких випадках податки нараховується з урахуванням діючих обмежень.

Висновки. Таким чином, в митному законодавстві застосовується чотирнадцять митних режимів, кожен з яких має свої умови та вимоги застосування, певні обмеження, а також податкові наслідки щодо митних платежів, податку на додану вартість та акцизного податку. Окрім того при застосуванні ризиків можуть виникати ризики для держави та суб'єктів підприємництва.

Митні режими дозволяють вибудовувати зовнішньоекономічні відносини та визначати напрями розвитку зовнішньої торгівлі, активізують ЗЕД і розвиток суб'єктів господарювання 3 урахуванням їх потреб та інтересів через стимулювання прогресивних змін з боку держави та фрормування чесного взаємовигідного співробітництва між суб'єктами господарювання та державою.

В умовах євроінтеграції України доцільним $€$ приведення митного законодавства України до вимог митного законодавства ЄС, в тому числі щодо митних режимів, які в митному законодавстві $€ C$ розуміються як митні процедури. Запровадження європейського досвіду має дозволити спростити митні процедури та підвищити ефективність митного контролю, зменшити час на офрормлення митних формальностей та має сприяти збільшенню торгівлі між Україною та країнами ЄС.

\section{СПИСОК ВИКОРИСТАНИХ ДЖЕРЕЛ:}

1. Лемеха Р. Класисрікація митних режимів за національним і європейським законодавством: уніфрікація підходів у контексті євроінтеграції. Адміністративне право і процес. 2020. № 10. С. 118-124. DOI: https://doi.org/10.32849/2663-5313/2020.10.20

2. Осадча Н., Ляшенко В. Митні режими як інститути стимулювання та обмеження зовнішньоекономічної діяльності. Формування ринкової економіки. 2010. С. 341-354.

3. Кормич Б. Митні режими або митні процедури: європейські стандарти термінології та класифікації. Lex portus. 2017. № 2. P. 142-153.

4. Тучак Т., Могильска М. Особливості застосування митних режимів України в умовах інтеграції до ЄС. Східна Європа: економіка, бізнес та управління. 2018. № 6(17). С. 52-55.

5. Митний кодекс України : Закон України від 13.03.2012 р. № 4495-VI. URL: https://zakon.rada.gov.ua/laws/ show/4495-17\#Text

6. Осадча Н. Державне регулювання інституційних змін у митній політиці : авторефр. дис. д-ра екон. наук. Донецьк, 2014.

7. Ляшенко В.И. Финансово-регуляторные режимы стимулирования экономического развития : монограсия. Донецк : Ин-т экономики пром-сти, 2012.

8. Науменко В.П. Применение таможенных режимов в Украине: теория, практика, рекомендации : практ. пособие. Киев : Знання, 2005.

9. Гребельник О.П. Митна справа : підручник. Київ : Центр учбової літератури, 2014.

10. Мельник М.В. Правове регулювання митних режимів в Україні : авторефр. дис. канд. юрид. наук. Київ, 2012.

11. Дубініна А.А. Митна справа : підручник. Київ : Центр учбової літератури, 2010.

12. Регламент Європейського Парламенту і Ради (ЄС) про встановлення Митного кодексу Союзу: від 9 жовтня 2013 р. № 952/2013. URL: https://zakon.rada.gov.ua/laws/show/984_009-13\#Text

13. Мостовий А. Функції митних режимів: порівняльна характеристика з митним правом Європейського Союзу. Вісник Львівського університету. 2008. № 47. С. 90-95.

14. Податковий кодекс України : Закон України від 02.12.2010 р. № 2755-VI. URL: https://zakon.rada.gov.ua/ laws/show/2755-17

15. Про Митний тарифр : Закон України від 04.06.2020 р. № 674-IX. URL: https://zakon.rada.gov.ua/laws/ show/674-20\#Text

16. Про виконання митних фрормальностей відповідно до заявленого митного режиму : наказ Міністерства фрінансів України від 31.05.2012 р. № 657. URL: https://zakon.rada.gov.ua/laws/show/z1669-12

17. Бюджет України. Статистичний збірник Міністерства фрінансів України. URL: https://mof.gov.ua/uk/ statistichnij-zbirnik 


\section{REFERENCES:}

1. Lemekha, R. (2020) Klasyfikatsiya mytnykh rezhymiv za natsional'nym i yevropeys'kym zakonodavstvom: unifikatsiya pidkhodiv u konteksti yevrointehratsiyi [Classification of customs regimes according to national and European legislation: unification of approaches in the context of European integration]. Administratyvne pravo $i$ protses, 10, 118-124. DOI: https://doi.org/10.32849/2663-5313/2020.10.20 (in Ukranian)

2. Osadcha, N. \& Lyashenko, V. (2010) Mytni rezhymy yak instytuty stymulyuvannya ta obmezhennya zovnishn'oekonomichnoyi diyal'nosti [Customs regimes as institutions of stimulation and restriction of foreign economic activity]. Formuvannya rynkovoyi ekonomiky, 341-354. (in Ukranian)

3. Kormych, B. (2017) Mytni rezhymy abo mytni protsedury: yevropeys'ki standarty terminolohiyi ta klasyfikatsiyi [Customs regimes or customs procedures: European standards of terminology and classification]. Lex portus, 2 , 142-153. (in Ukranian)

4. Tuchak, T. \& Mohyl'ska, M. (2018) Osoblyvosti zastosuvannya mytnykh rezhymiv Ukrayiny v umovakh intehratsiyi do YES [Features of application of customs regimes of Ukraine in the conditions of integration into the EU]. Skhidna Yevropa: ekonomika, biznes ta upravlinnya, 6(17), 52-55. (in Ukranian)

5. Mytnyy kodeks Ukrayiny : Zakon Ukrayiny vid 13.03.2012 r. no. 4495-VI [Customs Code of Ukraine: Law of Ukraine of March 13, 2012 № 4495-VI]. Available at: https://zakon.rada.gov.ua/laws/show/4495-17\#Text (in Ukrainian)

6. Osadcha, N. (2014) Derzhavne rehulyuvannya instytutsiynykh zmin u mytniy politytsi [State regulation of institutional changes in customs policy]: Author's dissertation of Dr. of Economics. Donets'k. (in Ukrainian)

7. Lyashenko, V. I. (2012) Finansovo-regulyatornyye rezhimy stimulirovaniya ekonomicheskogo razvitiya [Financial and regulatory regimes for stimulating economic development]. Donetsk: In-t ekonomiki prom-sti. (in Ukrainian)

8. Naumenko, V. P. (2005) Primeneniye tamozhennykh rezhimov v Ukraine: teoriya, praktika, rekomendatsii [Application of customs regimes in Ukraine: theory, practice, recommendations]. Kyiv: Znannya. (in Ukrainian)

9. Hrebelnyk, O. P. (2014). Mytna sprava [Customs]. Kyiv: Tsentr uchbovoyi literatury. (in Ukrainian)

10. Melnyk, M. V. (2012) Pravove rehulyuvannya mytnykh rezhymiv v Ukrayini [Legal regulation of customs regimes in Ukraine]: Author's dissertation. Candidate of Juridical Sciences. Kyiv. (in Ukrainian)

11.Dubinina, A. A. (2010) Mytna sprava [Customs]. Kyiv: Tsentr uchbovoyi literatury. (in Ukrainian)

12. Rehlament Yevropeys'koho Parlamentu i Rady (YES) pro vstanovlennya Mytnoho kodeksu Soyuzu: vid 9 zhovtnya 2013 r. No 952/2013 [Regulation of the European Parliament and of the Council establishing the Union Customs Code: 9 October 2013 № 952/2013]. Available at: https://zakon.rada.gov.ua/laws/show/984_009-13\#Text (in EU)

13. Mostovyy, A. (2008) Funktsiyi mytnykh rezhymiv: porivnyal'na kharakterystyka z mytnym pravom Yevropeys'koho Soyuzu [Functions of customs regimes: comparative characteristics with the customs law of the European Union]. Visnyk L'vivs'koho universytetu, 47, 90-95. (in Ukrainian)

14. Podatkovyi kodeks Ukrainy: Zakon Ukrainy vid 02.12 .2010 r. no. 2755 [Tax code of Ukraine: Law of Ukraine from 02.12.2010 No. 2755]. Available at: https://zakon.rada.gov.ua/laws/main/2755-17 (in Ukrainian)

15. Pro Mytnyy taryf: Zakon Ukrayiny vid 04.06 .2020 r. no. 674-IX [About the Customs Tariff: Law of Ukraine of 04.06.2020 no. 674-IX]. Available at: https://zakon.rada.gov.ua/laws/show/674-20\#Text (in Ukrainian)

16. Pro vykonannya mytnykh formal'nostey vidpovidno do zayavlenoho mytnoho rezhymu: nakaz Ministerstva finansiv Ukrayiny vid 31.05.2012 r. no. 657 [On fulfillment of customs formalities in accordance with the declared customs regime: order of the Ministry of Finance of Ukraine dated 31.05 .2012 no. 657]. Available at: https://zakon.rada.gov.ua/laws/show/z1669-12 (in Ukrainian)

17. Byudzhet Ukrayiny. Statystychnyy zbirnyk Ministerstva finansiv Ukrayiny [Budget of Ukraine. Statistical collection of the Ministry of Finance of Ukraine]. Available at: https://mof.gov.ua/uk/statistichnij-zbirnik (in Ukrainian) 